\author{
${ }^{1 *}$ S.Zh. Kolumbayeva ${ }^{(i D), ~}{ }^{1}$ A.V. Lovinskaya ${ }^{(i D)}$, \\ ${ }^{1}$ N.T. Bekmagambetova ${ }^{(D)},{ }^{2}$ S.K. Abilev \\ ${ }^{1}$ Al-Farabi Kazakh National University, Almaty, Kazakhstan \\ ${ }^{2}$ Vavilov Institute of General Genetics, Russia, Moscow \\ ${ }^{3}$ Lomonosov Moscow State University, Russia, Moscow \\ e-mail: saule.kolumbayeva@kaznu.kz
}

\title{
Antimutagenic activity of medicinal plants Salvia officinalis L. and Origanum vulgare L. (family Lamiaceae)
}

\begin{abstract}
The search for effective protectors of natural origin to correct mutagenic and toxic effects does not lose its relevance due to the increase of environmentally hazardous factors in the environment. The mutagenic and antimutagenic effect on chromosomal aberrations in root tips of barley seeds germinated under infusions of medicinal plants of oregano (Origanum vulgare) and sage (Salvia officinalis) of the Lamiaceae family were investigated. The studied infusion with different methods of preparation (concentrated, diluted, and phytotea) did not show a mutagenic effect, the frequency of structural mutations in barley seeds treated with infusions was at the level of negative control. The ability of oregano and sage infusions to reduce induced mutagenesis was also established. The frequency of mutagen-induced chromosomal aberrations decreased statistically significant $(p<0.01)$ in the combined pre- and posttreatment of each infusion with methyl methanesulfonate (MMS, positive control). The level of inhibition of the mutation process depended on the sequence of treatment to infusions and mutagen, as well as the type of infusion. A comparative analysis of the results of combined treatment of barley seeds with mutagen and infusions of oregano and sage showed that the pretreatment infusions before mutagen more effectively reduces the level of induced mutagenesis than the posttreatment. The effectiveness of the antimutagenic action of the studied infusions evaluated by the reduction factor. The reduction factor in the infusion of diluted oregano and oregano tea was above $60 \%$, which indicates the ability to inhibit MMS induced mutagenesis by Origanum vulgare infusions by $60 \%$. The reduction factor of the concentrated sage infusion in barley seeds pretreatment with it was $51 \%$, diluted sage infusions and tea was $70 \%$ and $71 \%$, respectively. The reduction factor indicates the ability of Salvia officinalis infusions to inhibit MMS-induced mutagenesis by $50-70 \%$ with pretreatment on barley seeds. The obtained results indicate the presence of antimutagenic activity in the studied medicinal herbs due to the presence of different biologically active compounds. Infusions of medicinal plants of oregano and sage can recommend for the development of means of protecting the body from chemical mutagenic factors.
\end{abstract}

Key words: medicinal plants, biologically active compounds, mutagenic and antimutagenic activity, chromosomal aberrations.

\section{Introduction}

The ecological situation in Kazakhstan, as well as in the whole world, is far from prosperous and firstly caused by large-scale pollution of the environment by ecologically dangerous factors with toxic and mutagenic activity. Recently, an increase in the frequency of oncological and hereditary diseases has been observed, which poses a severe threat to the human population [1-3]. There is an increase in the genetic load in the populations of almost all species of organisms, which can lead and is already leading to a sharp decline in the number and even the extinction of entire species. Sources of pollution, including road transport (flue gases), various industries (industrial waste, garbage), agriculture (pesticides, fertilizers), mining and processing industry, space industry are everywhere and contaminate the environment $[4 ; 5]$. The vast majority of environmental pollutants have toxic, cytotoxic, teratogenic effects. They are also likely to have carcinogenic and mutagenic activity [6]. In the body, they can activate free radicals, inhibit repair, or interact directly with DNA molecules. An essential role in the protection of genetic material and heredity is played by antimutagens, which can 
neutralize the mutagen before it interacts with DNA and suppress its action, as well as activate the repair system [2;7]. Therefore, the development and search for new sources of compounds with protective properties are undoubtedly relevant $[8 ; 9]$. Currently, chemically pure compounds and extracts from plants are used for this purpose. Antimutagenic properties have been identified in vitamins, amino acids, polyamines, endogenous antioxidants, and others. However, pure chemical compounds with antimutagenic action can have side effects. In this regard, drugs of natural origin are of great interest [7]. Besides, the process of obtaining drugs from plants is often more economically preferable than chemical synthesis [8].

Currently, medicinal plants arouse great interest as a promising source of biologically active compounds (BACs) with antioxidant and antimutagenic properties. Such substances can be used for a long time without harmful effects and have a complex effect on the body, as well as are relatively less allergenic in comparison with the synthetic analogs [10-13].

In Kazakhstan grows such medicinal species of plants of Lamiaceae family as Salvia (sage), Mentha (mint), Melissa (melissa), Leonurus (motherwort). Due to the phytochemical composition, medicinal plants of our republic have a broad pharmacological spectrum [14]. Therefore, screening of plants for genoprotective and antimutagenic potential is extremely promising. Screening and sampling of the most effective medicinal plants will allow us to offer certain species to create a collection of medicinal herbs that has genoprotective activity. The aim of the current research is the cytogenetic study of the mutagenic and antimutagenic activity of oregano (Origanum vulgare) and sage (Salvia officinalis) infusions of the Lamiaceae family on barley.

\section{Materials and methods}

Research objects. Barley of Baisheshek variety, which is zoned in Kazakhstan, was used for cytogenetic studies. Seeds of double-row barley (Hordeum vulgare L.) are widely used in cytogenetic studies, due to the small number $(2 n=14)$ and large size of chromosomes (length 6-8 microns). Another advantage of barley as a test object is the low natural mutation rate. At the same time, barley seeds have a sufficiently high sensitivity to various factors with mutagenic activity. Also, barley is widely used in various studies on the biotesting of xenobiotics for mutagenicity and antimutagenicity [15].

Medicinal plants of the Lamiaceae family oregano (Origanum vulgare) and sage (Salvia officinalis) were tested for antimutagenic activity. These herbs are rich in tannins, ascorbic acid, alkaloids, flavonoids, so they are in demand in traditional medicine. The natural level of mutation in seeds germinated on distilled water served as negative control. The standard mutagen methyl methanesulfonate (MMS, $\mathrm{C}_{2} \mathrm{H}_{6} \mathrm{O}_{3} \mathrm{~S}$ ), a potent directacting alkylating agent, was used as positive control at a concentration of $10 \mathrm{mg} / \mathrm{L}$ [16]. MMS in standard short-term in vivo and in vitro tests shows mutagenic activity, in the $u m u$-test induces the SOS response, in bacteria in the absence of metabolic activation induces point mutations. It also causes somatic and sex-linked recessive lethal mutations in Drosophila, induces neoplastic transformation in rodent cell cultures, in vivo causes mutations in germ cells of mice and in human cells in vitro causes the formation of micronuclei, single-strand DNA breaks, unscheduled DNA synthesis, gene mutations, and sister chromatid exchanges. The wide range of genetic activity shown above in the battery of different test systems explains the choice of methyl methanesulfonate as a positive control of genotoxic and mutagenic agents $[16 ; 17]$.

Seed germination and cytogenic test. Barley seeds were treated separately with infusions of medicinal plants and mutagen before germination. Infusions were prepared according to the recipe on the pharmacy packaging. Three types of infusions were studied for mutagenic/antimutagenic activity: concentrated (according to the recipe), diluted (concentrated infusion diluted 2 times) and phytotea. To identify the antimutagenic activity of the studied plants, a combined treatment of barley with infusions and mutagen was performed. Seeds were taken in each infusion for $4 \mathrm{~h}$. The treated seeds were washed and germinated in Petri dishes on filter paper moistened with distilled water in a thermostat at $25 \pm 1{ }^{\circ} \mathrm{C}$. A day later, germinated seeds with a length of primary roots $0.5 \mathrm{~cm}$ were transferred to filter paper moistened with a solution of $0.01 \%$ colchicine for 4 hours to accumulate metaphase plates. Then the roots were fixed using fixative (1:1 ethyl alcohol: glacial acetic acid), and after $24 \mathrm{~h}$, they were transferred to $70 \%$ ethanol for long-term storage [18].

The fixed material was cold hydrolyzed in a diluted aqueous (1:1) cooled $\mathrm{HCl}$ solution for 40-50 min at $4^{\circ} \mathrm{C}$. As a result of weak DNA hydrolysis, 
free aldehyde groups are formed, which interact with the stain, and the chromosomes acquire a bright purple color. After staining, the roots were washed with freshly prepared sulphurous water to remove the stain that had not reacted with DNA from the cells. Next, maceration was carried out with the help of cytase (a mixture of cellulitic enzymes of the salivary gland of the grape snail), which destroys the intercellular substance and plant cell walls, contributing to the distribution of a monolayer of metaphase plates on the slide. The obtained cytological preparations were kept in a refrigerating chamber for $24 \mathrm{~h}$ at $74 \pm 1^{\circ} \mathrm{C}$ to obtain permanent preparations.

To determine the mutagenic/antimutagenic potential of infusions of medicinal plants, we used a metaphase method of chromosome analysis. It is widely used by researchers cytogenetic test provides information about the types of structural mutations and their frequency $[1 ; 19]$. Metaphase plates were analyzed on the optical microscope Olympus BX 43F (Olympus, Japan). About 500 metaphases were analyzed in each variant. The effectiveness of reducing the frequency of MMS-induced chromosomal aberrations (the effectiveness of antimutagens) was determined by the reduction factor (RF). The antimutagenic effect was considered moderate for $25-40 \%$ inhibition, strong for more than $40 \%$, and not recognized as a positive result for less than $25 \%$ inhibition.

Statistical analysis. Statistical analysis of the results was carried out using the Analysis ToolPak in Microsoft Excel, Star Plus, and WinPepi. In each variant, the mean values and the standard errors of the means were calculated. Student's test was used to establish the reliability of differences between mean values of the different variants. The differences between the data were considered statistically significant with a confidence probability of 0.95 .

\section{Results and discussion}

Analysis of the genetic activity of oregano and sage infusions was performed in two stages. At the first stage, mutagenic activity of infusions of different concentrations was studied in order to select such variants that would not give a mutagenic effect. At the second stage, DNA-protective activity of infusions was studied at combined action with mutagen on barley seeds.

The study of mutagenic and antimutagenic activity of oregano (Origanum vulgare L.). The results of cytogenetic study of the root tip cells of barley seeds separately and combined treated with MMS and infusions of different concentrations of oregano presented in Table 1.

Table 1 - Frequency and spectrum of structural chromosome disorders induced in barley seeds by separate and combined treatment with methyl methanesulfonate and oregano infusions

\begin{tabular}{|c|c|c|c|c|c|}
\hline \multirow{2}{*}{ Experiment variation } & \multirow{2}{*}{$\begin{array}{l}\text { Total } \\
\text { studied } \\
\text { cells }\end{array}$} & \multirow{2}{*}{$\begin{array}{l}\text { Frequency of } \\
\text { aberrant cells } \\
(\mathrm{M} \pm \mathrm{m} \%)\end{array}$} & \multicolumn{3}{|c|}{ 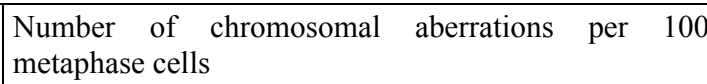 } \\
\hline & & & total aberrations & $\begin{array}{l}\text { chromosomal } \\
\text { type }\end{array}$ & chromatid type \\
\hline Water (negative control) & 480 & $1.25 \pm 0.51$ & $1.46 \pm 0.55$ & $0.83 \pm 0.41$ & $0.63 \pm 0.36$ \\
\hline MMS, $10 \mathrm{mg} / \mathrm{L}$ (positive control) & 450 & $5.33 \pm 1.06^{*}$ & $6.44 \pm 1.16^{*}$ & $2.22 \pm 0.69$ & $4.22 \pm 0.95 *$ \\
\hline Concentrated infusion & 495 & $1.82 \pm 0.60$ & $2.22 \pm 0.66$ & $0.81 \pm 0.40$ & $1.41 \pm 0.53$ \\
\hline Diluted infusion & 500 & $1.20 \pm 0.49$ & $1.20 \pm 0.49$ & $0.60 \pm 0.35$ & $0.60 \pm 0.35$ \\
\hline Phytotea & 490 & $1.22 \pm 0.50$ & $1.43 \pm 0.54$ & $0.61 \pm 0.35$ & $0.82 \pm 0.41$ \\
\hline Concentrated infusion + MMS & 500 & $3.60 \pm 0,83$ & $3.80 \pm 0.86$ & $1.40 \pm 0.53$ & $2.40 \pm 0.68$ \\
\hline Diluted infusion + MMS & 490 & $2.24 \pm 0,67^{\bullet}$ & $2.24 \pm 0.67^{\bullet \bullet}$ & $0.82 \pm 0.41$ & $1.43 \pm 0.54^{\bullet}$ \\
\hline Phytotea + MMS & 490 & $2.04 \pm 0.64^{\bullet \bullet}$ & $2.24 \pm 0.67^{\bullet \bullet}$ & $1.02 \pm 0.45$ & $1.22 \pm 0.50^{\bullet \bullet}$ \\
\hline MMS + concentrated infusion & 480 & $4.17 \pm 0.91$ & $4.58 \pm 0.95$ & $1.67 \pm 0.58$ & $2.92 \pm 0.77$ \\
\hline MMS + diluted infusion & 490 & $2.86 \pm 0.75$ & $3.06 \pm 0.78^{\bullet}$ & $1.02 \pm 0.45$ & $2.04 \pm 0.64$ \\
\hline MMS + phytotea & 510 & $2.94 \pm 0.75$ & $3.33 \pm 0.79^{\bullet}$ & $1.18 \pm 0.48$ & $2.16 \pm 0.64$ \\
\hline
\end{tabular}


From the results, the frequency of aberrant cells in the control variant, when the seeds were germinated on distilled water, was $1.25 \%$. The number of chromosomal aberrations per 100 analyzed metaphases was already higher because in 1 cell were observed 2 chromosome structural abnormalities. The ratio of chromosomal and chromatid rearrangements was almost equal and amounted to $0.83 \%$ and $0.63 \%$, respectively.

The frequency of aberrant cells and the number of chromosomal aberrations per 100 metaphases in the cells of the root tip cells of MMS-treated seeds dramatically increased, compared to the control variant. The frequency of aberrant cells and the number of chromosomal aberrations per 100 metaphases significantly $(p<0.001)$ increased by 4.3 times. The increase in the level of chromosome rearrangements occurred both due to structural mutations of chromosomal and chromatid types. Moreover, the frequency of chromatid-type abnormalities increased by 6.7 times $(p<0.001)$, and the chromosome type - by 2.7 times. The obtained results indicate a high sensitivity of the genetic material to the mutagenic action of MMS in the synthesis phase $(\mathrm{S})$ and postsynthetic phase $\left(\mathrm{G}_{2}\right)$ of the cell cycle. The spectrum of chromosomal aberrations was quite wide. Paired terminal deletions, paired point fragments represented chromosomal rearrangements, chromatid-type were represented by single terminal fragments and acentric single rings. Besides, it was noted abnormal anaphases, which were absent in the negative control (Figure 1).
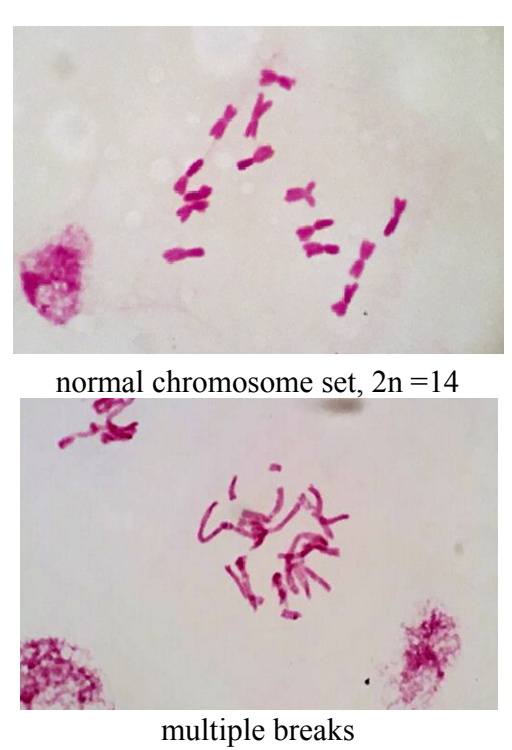

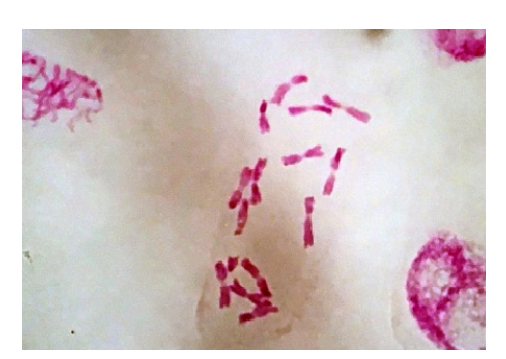

paired end deletion

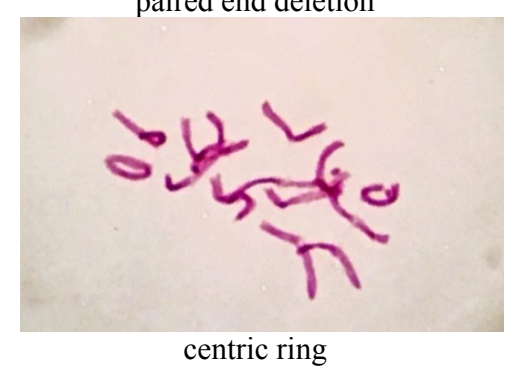

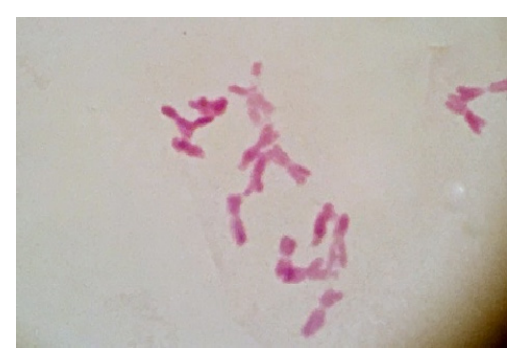

chromatid deletion

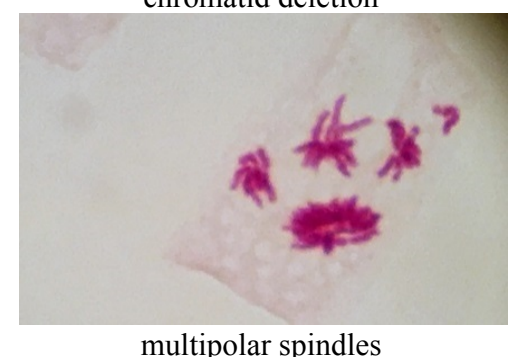

Figure 1 - Structural chromosome disorders induced by MMS, x1000

Treatment of seeds with oregano infusions of different concentrations did not show any mutagenic effect. The level of chromosomal aberrations in all three variants of seed treatment with infusions was at the same level as control. There was an increase of 1.5 times in the frequency of aberrant cells and the number of chromosomal aberrations per 100 metaphases in the treatment of seeds with a concentrated oregano infusion compared to the control, but this difference was not statistically significant. Therefore, the results obtained in this series of experiments indicate the absence of mutagenic activity in oregano infusions in the used concentrations.

In the next series of experiments was studied, the ability of oregano infusions to modify the mutagenic effect of methyl methanesulfonate in their combined effect on barley seeds (Table 2). 
Table 2 - Frequency and spectrum of structural chromosome disorders induced in barley seeds by separate and combined treatment with methyl methanesulfonate and sage infusions

\begin{tabular}{|c|c|c|c|c|c|}
\hline \multirow{2}{*}{ Experiment variation } & \multirow{2}{*}{$\begin{array}{c}\text { Total } \\
\text { studied } \\
\text { cells } \\
\end{array}$} & \multirow{2}{*}{$\begin{array}{l}\text { Frequency of } \\
\text { aberrant cells } \\
(\mathrm{M} \pm \mathrm{m} \%)\end{array}$} & \multicolumn{3}{|c|}{$\begin{array}{l}\text { Number of chromosomal aberrations per } \\
100 \text { metaphase cells }\end{array}$} \\
\hline & & & total aberrations & chromosomal type & chromatid type \\
\hline Water (negative control) & 480 & $1.25 \pm 0.51$ & $1.46 \pm 0.55$ & $0.83 \pm 0.41$ & $0.63 \pm 0.36$ \\
\hline MMS, $10 \mathrm{mg} / \mathrm{L}$ (positive control) & 450 & $5.33 \pm 1.06^{*}$ & $6.44 \pm 1.16^{*}$ & $2.22 \pm 0.06$ & $4.22 \pm 0.95 *$ \\
\hline Concentrated infusion & 510 & $2.16 \pm 0.64$ & $2.94 \pm 0.75$ & $1.18 \pm 0.48$ & $1.76 \pm 0.58$ \\
\hline Diluted infusion & 490 & $1.43 \pm 0.54$ & $1.63 \pm 0.57$ & $0.82 \pm 0.41$ & $0.82 \pm 0.41$ \\
\hline Phytotea & 475 & $1.68 \pm 0.59$ & $1.68 \pm 0.59$ & $1.05 \pm 0.47$ & $0.63 \pm 0.36$ \\
\hline Concentrated infusion + MMS & 540 & $2.78 \pm 0.71^{\bullet}$ & $3.15 \pm 0.75^{\bullet}$ & $1.30 \pm 0.49$ & $1.85 \pm 0.58^{\bullet}$ \\
\hline Diluted infusion + MMS & 510 & $1.76 \pm 0.58^{\bullet \bullet}$ & $1.96 \pm 0.61^{\bullet \bullet \bullet}$ & $0.78 \pm 0.39$ & $1.18 \pm 0.48^{\bullet \bullet}$ \\
\hline Phytotea + MMS & 490 & $1.84 \pm 0.61^{\bullet \bullet}$ & $1.84 \pm 0.61^{\bullet \bullet \bullet}$ & $0.82 \pm 0.41$ & $1.02 \pm 0.45^{\bullet \bullet}$ \\
\hline MMS + concentrated infusion & 480 & $3.13 \pm 0.79$ & $3.75 \pm 0.87$ & $1.46 \pm 0.55$ & $2.29 \pm 0.68$ \\
\hline MMS + diluted infusion & 515 & $3.11 \pm 0.76$ & $3.30 \pm 0.79^{\bullet}$ & $1.36 \pm 0.51$ & $1.94 \pm 0.61^{\bullet}$ \\
\hline MMS + phytotea & 510 & $3.14 \pm 0.77$ & $3.53 \pm 0.82^{\bullet}$ & $1.18 \pm 0.48$ & $2.36 \pm 0.67$ \\
\hline
\end{tabular}

As can be seen from the presented results, pretreatment of barley seeds with concentrated infusion of oregano reduced the occurrence of MMS-induced structural mutations by 1.7 times. However, the observed decrease was not statistically significant.

As a result of pretreatment of seeds with diluted oregano infusion and oregano phytotea with subsequent treatment of MMS, a statistically significant decrease in the level of MMS-induced mutagenesis was observed. In the variant with a diluted infusion, the frequency of aberrant cells induced by MMS was reduced by 2.3 times $(p<0.05)$. The number of chromosomal aberrations per 100 metaphases decreased by 2.9 times $(\mathrm{p}<0.01)$ compared to the MMS treatment. The decrease in the level of chromosomal aberrations occurred both due to rearrangements of chromosomal and chromatid types. There was a statistically significant $(p<0.05)$ decrease in the level of chromatid rearrangements.

Oregano phytotea also significantly reduced the frequency of aberrant cells and the level of chromosomal aberrations induced by the mutagen. Thus, the frequency of cells with chromosome rearrangements induced by MMS decreased from $5.33 \%$ to $2.04 \%$, i.e., 2.6 times $(p<0.01)$. The number of chromosomal aberrations per 100 cells decreased from $6.44 \%$ to $2.24 \%$, which was 2.9 times $(p<0.01)$. At the same time, there was a statistically significant decrease in the level of structural rearrangements of chromatid type $(\mathrm{p}<0.01)$.

In the seed posttreatment (first mutagen, and then treatment with infusion), the modifying effect mutagenic action of MMS was slightly different. So, in the posttreatment of concentrated oregano infusion after mutagen, the frequency of aberrant cells decreased by 1.3 times compared to the variant of separate treatment of MMS, and the number of chromosomal aberrations per 100 cells - by 1.4 times. The level of chromosomal rearrangements decreased by 1.3 times, and chromatid type - by 1.5 times. However, the observed decrease in MMSinduced mutagenesis was not statistically significant. In variants with seed posttreatment with diluted oregano infusion and oregano phytotea after MMS, a statistically significant decrease in the number of chromosomal aberrations per 100 cells was observed, by 2.1 times $(\mathrm{p}<0.05)$ and 1,9 times $(\mathrm{p}<0.05)$, respectively.

The obtained results indicate the ability of oregano infusions to modify methyl methanesulfonate-induced mutagenesis in the direction of its decrease. This fact allows us to assume that the complex of biologically active compounds contained in oregano has antimutagenic activity. Moreover, the antimutagenic activity of oregano infusions depends on their concentration. In this case, the concentrated infusion, in contrast to the diluted infusion and oregano tea, did not give a statistically significant antimutagenic effect. 
Comparative analysis of the results of combined treatment of barley seeds with mutagen and oregano infusions showed that the pretreatment of infusions effectively reduces the level of induced mutagenesis than the posttreatment.

The effectiveness of the antimutagenic action of oregano was evaluated by the reduction factor. The reduction factor in the diluted oregano infusion and oregano tea was above $60 \%$. It indicates the ability of Origanum vulgare infusions to inhibit the mutagenesis MMS-induced mutagenesis by $60 \%$. The obtained results suggest a strong antimutagenic effect, given by diluted infusions of the medicinal plant oregano that contains biologically active compounds.

The study of the mutagenic and antimutagenic activity of infusions from the medicinal plant sage (Salvia officinalis L.). Results of cytogenetic study of the barley root meristem cells separately and mutually treated with MMS and sage infusions of different concentrations are presented in Table 2. All variants of sage infusions in barley seed treatment did not significantly increase the frequency of aberrant cells and the level of chromosomal aberrations by 100 metaphases compared to the negative control. So, if these indicators in the control were $1.25 \%$ and 1.46 per 100 metaphases, then after seed treatments with concentrated, diluted infusions and phytotea indicators show $-2.16 \%$ and $2.94,1.43 \%$ and 1.63 , $1.68 \%$ and 1.68 , respectively. However, it should be noted that in the treatment with concentrated sage infusion, these indicators were higher by 1.7 and 2.0 times, respectively, but the difference was not statistically significant. The results in these experiment series indicate the absence of mutagenic activity in sage infusions in the used concentrations.

In the next series of experiments, barley seeds were successively treated first with sage infusions, and then with MMS mutagen in order to establish the presence or absence of antimutagenic potential in the infusions of this medicinal plant. In «concentrated infusion + MMS» combination (pretreatment) sage significantly reduced the frequency of aberrant cells and the number of chromosomal aberrations per 100 metaphases by 1.9 times $(\mathrm{p}<0.05)$ and 2.0 times $(\mathrm{p}<0.05)$, respectively, compared to MMS treatment. At the same time, there was a statistically significant decrease in the number of chromatid-type structural aberrations (single terminal fragments, acentric rings, micro fragments) by 2.3 times $(\mathrm{p}<0.05)$.
As a result of barley seed pretreatment with diluted sage infusion and sage phytotea, the inhibition degree of MMS-induced mutagenesis significantly increased. Thus, in the variant with a diluted sage infusion, the frequency of aberrant cells and the number of chromosomal aberrations per 100 metaphases decreased by $3.1(\mathrm{p}<0.01)$ and 3.3 times $(p<0.001)$, respectively, compared to treatment with MMS. A statistically significant decrease in these indicators happened due to structural rearrangements of the chromatid type $(p<0.01)$. Pretreatment with sage phytotea before MMS significantly reduced the occurrence of mutageninduced chromosomal aberrations. Also, the level of aberrant cells fell from $5.33 \%$ to $1.84 \%(\mathrm{p}<0.01)$, and the number of chromosomal aberrations per 100 metaphases decreased from 6.44 to $1.84(\mathrm{p}<0.001)$. In this variant, was observed a statistically significant $(p<0.01)$ decrease in the frequency of chromatid type rearrangements by 4.1 times.

In the seed posttreatment (MMS + sage), the effect of sage modification of MMS-induced mutagenesis was significantly weaker and was not noticed in all treatment variants. Thus, with barley posttreatment after a mutagen with concentrated infusion, there was a tendency to a decrease in all studied parameters, that is, the frequency of aberrant cells, the number of chromosomal aberrations by 100 metaphases and the number of rearrangements of the chromosomal and chromatid types. However, the observed decrease in the level of MMS-induced mutagenesis was not statistically significant.

In variants with seed posttreatments with diluted sage infusion and sage phytotea after MMS, there was a statistically significant decrease in the number of chromosomal aberrations per 100 cells by 2.0 and 1.8 times $(p<0.05)$, respectively. The number of structural mutations of chromatid type $(\mathrm{p}<0.05)$ also significantly decreased in the variant with seed posttreatment with diluted infusion after MMS.

The obtained results indicate the ability of sage infusions, depending on its concentration, to significantly modify the level of induced mutagenesis in the direction of its decrease. When sage infusions exposures combined with mutagen, there was a statistically significant decrease in the frequency of chromosomal aberrations induced by MMS. It should be noted, that the degree of inhibition of induced mutagenesis depended not only on the concentration of infusions, but also on the sequence of their treatment on the studied test object. 
This fact allows us to assume that the complex of biologically active compounds contained in sage, has antimutagenic activity. Comparative analysis of the results of combined treatment of barley seeds with mutagen and sage infusions showed that the pretreatment of infusions reduces the level of induced mutagenesis more effectively than the posttreatment, same as in the case of oregano.

The effectiveness of the antimutagenic action of sage was evaluated by the reduction factor. The reduction factor in the pretreatment of barley seeds with concentrated infusion was $51 \%$, with diluted sage infusion and sage phytotea was $70 \%$ and $71 \%$, respectively. The reduction factor indicates the ability of Salvia officinalis infusions to inhibit MMS-induced mutagenesis by $50-70 \%$ in case of barley pretreatment. The reduction factor at the posttreatment after MMS influence of infusions was $49-45 \%$. The obtained results indicate the presence of antimutagenic activity in sage infusions, due to the presence of different biologically active compounds in plants of this species.

Thus, cytogenetic studies were carried out on barley seeds, separately and combined treated with infusions of different concentrations of two species of medicinal plants from the family Lamiaceae oregano (Origanum vulgare L.) and sage (Salvia officinalis L.). The established antimutagenic activity of infusions from medicinal plants was presented in a statistically significant decrease in the level of chromosomal aberrations induced by the classical mutagen methyl methanesulfonate. There were no statistically significant differences in the level of modification of the mutagenic effect of MMS with the studied infusions containing biologically active compounds.

Environmental pollution by hazardous agents with genetic activity significantly increases the risk of hereditary pathologies in newborns, malignant neoplasms and other diseases in the population. Therefore, one of the priorities of the state is its genetic safety. Within the framework of this problem, there is increasing interest in the process of reducing and leveling spontaneous or induced mutagenesis and in the general phenomenon of antimutagenesis. Therefore, the search and detection of compounds with antimutagenic activity are one of the most promising areas of research in recent years [9].

Numerous studies indicate that plants play an important role in maintaining human health. According to the World Health Organization, more than half of the world's population uses alternative medicine based on medicinal plants along with traditional medicine [20-22]. In recent decades, natural antioxidants have attracted attention for their protective effect, against toxicity and genotoxicity, caused by various physical and chemical agents. Many researchers note that the use in everyday life of various natural antimutagenic and antigenotoxic compounds that can reduce genetic material damage can prevent the development of cancer in humans [21-23]. There are two groups of antimutagens desmutagens and bioantimutagens. The desmutagen removes genotoxic agents from the body or inactivates mutagens partially or completely before interacting with DNA. Bioantimutagen can participate in the processes of repairing damaged DNA. The mechanism, effectiveness, and spectrum of action of antimutagens can be different $[1 ; 9 ; 24]$.

Currently, a large number of antimutagens of different nature have been revealed. The mechanism of action of many of them is still completely unknown, which is why they have not been widely used $[24 ; 25]$. In addition, the assessment of their harmlessness to the human has not been fully done, traditional pharmacotoxicological studies have not been carried out. This is why the search for inhibitors of induced mutagenesis among medicinal plants widely used in traditional medicine is the most promising. The antimutagenic effect of herbal preparations is due to the presence of biologically active compounds in them, primarily vitamins, phenols, polyphenols, pigments, amino acids and others [26;27].

Based on the above, we performed cytogenetic studies of antimutagenic activity of two species of medicinal plants from the family Lamiaceae that widely used in traditional medicine - oregano (Origanum vulgare L.) and sage (Salvia officinalis L.). Antimutagenic activity of infusions of these medicinal plants was demonstrated in a significant decrease in the frequency of chromosomal aberrations induced by the classical mutagen methyl methanesulfonate. There were no statistically significant differences in the level of modification of the mutagenic effect of MMS by infusions of different concentrations. Also, there were no statistically significant differences in the degree of antimutagenic activity of oregano and sage infusions with MMS-induced mutagenesis.

Origanum and Salvia plants from Lamiaceae family have anti-inflammatory, antioxidant, sedative, antibacterial, wound healing, toning, antiseptic effects, which are used in diseases of the upper respiratory tract and gastrointestinal tract. 
Sage leaves contain essential oils (up to $2 \%$ ) that include camphor, cineol, D- $\alpha$-pinene, $\alpha$ - and $\beta$ thujone, D-borneol, tannins, alkaloids, some acids, sodium, potassium, calcium, vitamins $\mathrm{A}, \mathrm{C}, \mathrm{E}, \mathrm{K}$, fiber and flavonoids. Oregano herb contains 0.3 to $1 \%$ essential oil, which includes phenols (up to $44 \%$ ) - thymol and its isomer carvacrol, bi- and tricyclic sesquiterpenes (12.5\%); tannins, ascorbic acid, and flavonoids.

The composition of medicinal plants includes many natural phenolic antioxidants, which cause their antioxidant, anti-inflammatory, antimicrobial, antispasmodic and neuroprotective effects. Phenolic and polyphenolic compounds are involved in redox reactions and in the processes of neutralization of reactive oxygen species. There is data on the presence of antimutagenic and anticancerogenic activity of polyphenols [28].

Phytochemicals influence the processes of metabolism and neutralization of xenobiotics, including carcinogens and mutagens. They can bind free radicals and reactive metabolites of xenobiotics, inhibit enzymes that activate xenobiotics, and activate detoxification enzymes [24]. A comprehensive study of plant compounds as potential protectors for the toxic, genotoxic and mutagenic effects of various environmental pollutants on the body is required.

\section{Conclusion}

In the present study, cytogenetic studies were carried out on barley seeds, separately and mutually with infusions of different concentrations of two species of medicinal plants from the family Lamiaceae - oregano (Origanum vulgare L.) and sage (Salvia officinalis L.). Antimutagenic activity of infusions from medicinal plants was noted by a statistically significant decrease in the level of chromosomal aberrations induced by the classical mutagen methyl methanesulfonate. No statistically significant differences in the level of modification of the mutagenic effect of MMS with the studied infusions containing biologically active compounds were revealed.

\section{References}

1. Abilev S.K., Glazer V.M. (2015) Mutagenez s osnovami genotoksikologii [Mutagenesis with the basics of genotoxicology]. Moscow; SaintPetersburg: Nestor-Istoriya, $304 \mathrm{p}$.
2. Mukhametzhanova Z.T. (2017) Sovremennoe sostoyanie problemy zagryazneniya okruzhayushchey sredy [Current state of the problem of environmental pollution]. Gigiena truda i meditsinskaya ekologiya, vol. 55, no 2, pp. 11-20.

3. Moroz V.V., Smirnova S.G., Ivanova O.V., Poroshenko G.G. (2007) Mutatsii i antimutageny v meditsine kriticheskikh sostoyaniy [Mutations and antimutagens in critical state medicine]. Obshchaya reanimatologiya, no. 5-6, pp. 213-217.

4. Kolumbayeva S.Zh., Begimbetova D.A. (2013) Mutagennye effekty khimicheskikh zagryazniteley okruzhayushchey sredy [Mutagenic effects of chemical environmental pollutants]. Almaty: Qazaq universiteti, 196 p.

5. Ilyushina N.A., Egorova O.V., Masal'tsev G.V., Aver'yanova N.S., Revazova Yu.A. (2017) Mutagennost' i kantserogennost' pestitsidov, opasnost' dlya zdorov'ya cheloveka. Sistematicheskiy obzor. [Mutagenicity and carcinogenicity of pesticides, danger to human health. Systematic review]. Zdravookhranenie Rossiyskoy Federatsii, vol. 61, no. 2, pp. 96-102.

6. Carpenter D.O. (2013) Exposure to chemicals and radiation during childhood and risk for cancer later in life. Journal of Adolescent Health, vol. 52, no. 5, pp. S21-S29. doi: 10.1016/j.jadohealth.2013.01.027

7. Durnev A.D. (2018) Antimutagenez i antimutageny [Antimutagenesis and antimutagens]. Fiziologiya cheloveka, vol. 44, no. 3, pp. 116-137.

8. Efimov S.N., Dmitruk S.I., Il'inskikh N.N. (2004) Antimutagennaya aktivnost' lekarstvennykh rasteniy Sibirskogo regiona. [Antimutagenic activity of medicinal plants of the Siberian region] Byulleten' sibirskoy meditsiny, no. 3, pp. 17-26.

9. Słoczyńska K., Powroźnik B., Pękala E., Waszkielewicz A.M. (2014) Antimutagenic compounds and their possible mechanisms of action. J. Appl. Gen., vol. 55, no. 2, pp. 273-285. doi: $10.1007 / \mathrm{s} 13353-014-0198-9$

10. Safonov N.N. (2013) Lekarstvennye rasteniya: illyustrirovannyy atlas. [Medicinal plants: illustrated atlas]. M.: Eksmo, pp. 305-307.

11. Goncharova R.I., Kuzhir T.D. (2005) Molekulyarnye osnovy primeneniya antimutagenov $\mathrm{v}$ kachestve antikantserogenov. [Molecular basis of applying antimutagens as anticarcinogens] Ekologicheskaya genetika, vol. 3, no. 3, pp. 19-32.

12. Uzun F., Kalender S., Durak D. et al. (2009) Malathion-induced testicular toxicity in male rats and the protective effect of vitamins $\mathrm{C}$ and E. Food 
Chem. Toxic., vol. 47, no. 8, pp. 1903-1908. doi: 10.1016/j.fct.2009.05.001

13. Chen K.-H., Wang, K.-J., Wang K.-M. et al. (2014) Applying particle swarm optimization-based decision tree classifier for cancer classification on gene expression data. Appl. Soft Comp., vol. 24 (C), pp. 773-780. doi: 10.1016/j.asoc.2014.08.032.

14. Loseva I.V. (2008) Syr'evaya baza lekarstvennykh rasteniy Kazakhstana i ee ratsional'noe ispol'zovanie [The raw material base of medicinal plants of Kazakhstan and its rational use]. Karaganda, 110 p. (In Russian).

15. Georgieva M., Gecheff K. (2013) Molecular Cytogenetic Characterization of a New Reconstructed Barley Karyotype. Biotechnology and Biotechnological Equipment, vol. 27, no. 1, pp. 3577-3582. doi: 10.5504/BBEQ.2012.0126

16. Oshida K., Iwanaga E., Miyamoto K., Miyamoto Y. (2010) Comet assay in murine bonemarrow cell line (FDC-P2). Toxicol in vitro, vol. 24, no. 3, pp. 1039-1044. doi: 10.1016/j.tiv.2009.11.014

17. Smirnikhina S.A., Strelnikov V.V., Voronina E.S., Tanas A.S., Lavrov A.V. (2013) Mutagen influence with different mechanisms of action on DNA global methylation in human wholeblood lymphocytes in vitro. Rus J Gen., vol. 49, no. 7, pp. 765-770. doi: 10.1134/S1022795413060124

18. Pausheva Z.P. (1988) Praktikum po tsitologii rasteniy [Practicum on plant cytology]. Moscow: Agropromizdat, $271 \mathrm{p}$.

19. Daev E.V., Dukel'skaya A.V., Barabanova L.V. (2014) Tsitogeneticheskie metody indikatsii ekologicheskoy napryazhennosti $\mathrm{v}$ vodnykh i nazemnykh biosistemakh [Cytogenetic methods for indicating environmental stress in aquatic and terrestrial biosystems]. Ekol. genetika, vol.12, no. 2, pp. 3-12.

20. Mendoza-Pérez J.A., Fregoso-Aguilar T.A. (2013) Chemistry of natural antioxidants and studies performed with different plants collected in Mexico. Rijeka, Croatia: InTech, pp. 59-85.

21. Barranco-Pedraza L.M., Batista-Hernández I.L. (2013) Social contribution of traditional and natural medicine in the Cuban public health. Rev. Human Med., vol.3, no. 13, pp. 713-727.
22. López-Romero D., Izquierdo-Vega J.A., Morales-González J.A., Madrigal-Bujaidar E., Chamorro-Cevallos G., Sánchez-Gutiérrez M., Betanzos-Cabrera G., Álvarez-González I., MoralesGonzález Á., Madrigal-Santillán E. (2018) Evidence of Some Natural Products with Antigenotoxic Effects. Part 2: Plants, Vegetables, and Natural Resin. Nutrients, vol. 10, no. 12, pp. 1954. doi: 10.3390/nu10121954

23. Madrigal-Santillán E., Madrigal-Bujaidar E., Cruz-Jaime S., Valadez-Vega M.C., SumayaMartínez M.T., Pérez-Ávila K.G., MoralesGonzález J.A. (2013) The Chemoprevention of Chronic Degenerative Disease Through Dietary Antioxidants: Progress, Promise and Evidences. Rijeka, Croatia: InTech, pp. 155-185.

24. Morales-González J.A., Madrigal-Bujaidar E., Sánchez-Gutiérrez M., Izquierdo-Vega J.A. (2019) Garlic (Allium sativum L.) A brief review of its antigenotoxic effects. Foods, vol. 8, no. 8, pp. 343. doi: 10.3390/foods 8080343

25. Mosovska S., Mikulasova M., Brindzova L. (2010) Genotoxic and antimutagenic activities of extracts from pseudocereals in the Salmonella mutagenicity assay. Food Chem. Toxicol., Vol. 48, no. 6 , pp. 1483-1487.

26. Ammosov A.S., Litvinenko V.I. (2003) Fenol'nye soedineniya rodov Glycyrrhiza L. i Meristotropis Fisch. et Mey [Phenolic compounds of the genera Glycyrrhiza L. and Meristotropis Fisch. et Mey]. Farmakom., no. 2, pp. 34-80.

27. Vasilyeva I.M., Shagirova Zh.M., Sinelshikova T.A., Mavletova D.A., Kuzmina N.S., Zasukhina G.D. (2009) Protection of radiosensitive human cells against the action of heavy metals by antimutagens and adapting factors: assotiation with genetic and protein polymorphisms. Rus J Gen., vol. 45, no 6, pp. 659-662. doi: 10.1134/S1022795409060040

28. Maslennikov P.V., Chupakhina G.N., Skrypnik L.N. (2013) Soderzhanie fenol'nykh soedineniy $\mathrm{v}$ lekarstvennykh rasteniyakh botanicheskogo sada. [The content of phenolic compounds in medicinal plants of the botanical garden] Izvestiya RAN. Seriya biologicheskaya, no. 5, pp. 551-557. 